$\mathrm{PhD}$ in Pedagogy, Academic Secretary, OLENA TRYNUS Institute for Pedagogical Education and Adult Education, the NAPS of Ukraine Address: 9 M. Berlynskyi St., Kyiv, 04060, Ukraine E-mail: evtrinus@gmail.com

\title{
INFLUENCE OF WESTERN EUROPEAN PEDAGOGICAL TRENDS ON DEVELOPMENT OF YOUNG TEACHER'S PEDAGOGICAL MASTERY IN THE LATE 19TH - THE EARLY 20TH CENTURIES
}

\begin{abstract}
The end of the 19th and early 20th centuries is characterized by justification of reforming pedagogical trends in Western Europe and accumulation of relevant ideas required to create a new type of school, educate independent and initiative individuals and improve teacher training. Based on comparative pedagogical analysis of the mentioned period, the content of individualistic (free creativity of students and teachers), experimental (studying general patterns and individual characteristics of students' physical and spiritual development), social (establishing relationships between education and community), Herbartinian (educational teaching, development of various interests), monistic (methodological principle of continuity in cognition, unity and invariance of world laws) pedagogical trends have been analyzed. It has been found that the conceptual foundation for foreign pedagogical trends was the study of personality traits of the student as "the object of pedagogical influence", and their unifying basis was a well-developed personality of the student as well as their cognitive activity. It has been revealed that young teachers are primarily responsible for developing active, independent, creative personalities, able to change the world around. It has been determined that an important factor in developing their pedagogical mastery is the ability to analyze and use innovative ideas of representatives of the latest pedagogical trends, to master new educational technologies, methods and, of course, special skills in developing the child's personality. It has been proved that young teachers' career success is associated with development of their personal qualities, namely, friendliness, humanity, great love and care for children.

Keywords: Western European pedagogical trends, teacher, young teacher, student personality, independence, cognitive activity, advanced educational technologies, teaching methods.

\section{INTRODUCTION}

At the current stage of developing the Ukrainian state, the problem of reforming the national school education is of great significance. The main principle of future transformations should consist in educating the younger generation and enhancing a high culture and equal opportunities (Ministerstvo osvity i nauky Ukrainy, 2016). Thus, there appears to be a need for quality training of teaching staff, who should be creative, have a high level of pedagogical mastery and professional competency and be able to self-develop. Graduate teachers, who only start their teaching career, should become "the agents of changes" of a modern Ukrainian school and therefore reform educational space for the next decades. Under these conditions, foreign experience in education development and its creative implementation into the national pedagogical theory and practice are rather important.
\end{abstract}


One should pay particular attention to the analysis of historical and pedagogical experience in conducting comparative pedagogical researches in the late 19th - the early 20th centuries, when the ideas of reformatory pedagogy emerged, the diversity of pedagogical concepts was justified, a new type of secondary school aimed at educating independent and initiative individuals who are able to creatively use the acquired knowledge was established and eventually the conditions for teachers' personal and professional development were provided.

\section{THE AIM OF THE STUDY}

The aim of the study consists in studying the ideas of reformatory pedagogy in the late 19th - the early 20th centuries as well as the trends in using progressive experience in developing pedagogical mastery of young teachers.

\section{THEORETICAL FRAMEWORK AND RESESRCH METHODS}

The object of the study of comparative pedagogy in the late 19th - the early 20th centuries was advanced foreign pedagogical experience through the prism and priorities of the national school and pedagogy. It was believed that one of the most important trends in the state policy of the leading countries should be studying educational improvements all over the world and appointing government officials with significant powers for this matter (Muzychenko, 1919, p. 5).

Ukrainian scholars had the opportunity to study foreign experience by familiarizing themselves with the state education documents, professional literature and during intensive participation in the education process when abroad.

There were several approaches to conducting scientific researches on problems of foreign pedagogy according to the level of comparative analysis: elementary translations of scientific studies without any reductions and interferences; translation of the author's text with its further analysis; a thorough comparative pedagogical analysis of the text, taking into account the patterns of the national education system (Sukhomlynska, 1992, pp. 5-6).

Analyzing the state, patterns, trends in education development in different countries, Ukrainian comparatorists attempted to introduce the constructive aspects of foreign experience into theory and practice of developing a Ukrainian school and teacher training (S. Ananiin, M. Askerman, M. Bunge, G. Genkel, G. Grinko, A. Hotalov-Hotlib, M. Korf, O. Levitskiy, Ya. Mikhailovskyi, P. Mizhuev, A. Musin-Pushkin, A. Muzychenko, S. Rusova, E. Yanzhul et al.). The authors emphasized on importance of studying development of school systems in European countries (Genkel, 1911; Hotalov-Hotlib, 1929) and the USA (Yanzhul, 1918); analyzed the activity of educational institutions (Mizhuev, 1913; Musin-Pushkin, 1912; Rusova, 1910); studied the problem of professional pedagogical training of teachers (Bunge, 1877; Muzychenko, 1919); justified the ways of introducing progressive foreign experience in Ukraine (Ananiin, 1924; Askerman, 1915; Grinko, 1915; Korf, 1879; Levitskiy, 1912).

Of considerable interest are the works on the history of the national education of Ukraine (O. Antonova, L. Berezivska, N. Demianenko, N. Dichek, N. Kalenychenko, I. Likarchuk, V. Maiboroda, S. Melnychuk, B. Stuparyk, L. Vovk, M. Yarmachenko et al.); specificity of teachers' training in historical progress (N. Demchenko, N. Demianenko, H. Feshchenko, S. Honcharenko, Yu. Radchenko, O. Sukhomlynska et al.); theoretical and methodological foundations of pedagogical mastery development (Ye. Barbina, A. Kuzminskyi, O. Lavrinenko, M. Leschenko, O. Otych, L. Savenkova, O. Semenoh, M. Soldatenko, I. Ziaziun et al.). 
To conduct the research, a complex of interrelated general scientific, historical, theoretical and empirical methods was used: historical pedagogical analysis and synthesis, constructive genetic method, historical comparative method, historical pedagogical analysis of archival and literary sources.

\section{RESULTS}

The development of foreign pedagogical thought in the late 19th - the early 20th centuries was directly influenced by such philosophical trends as pragmatism, positivism, personalism, neo-Kantianism, as well as various psychological and sociological theories. There were two main paradigms, namely, pedagogical traditionalism that is continuation of the previous pedagogical thought and reformatory pedagogy or a new education development of new pedagogical concepts and ideas. Traditionalism refers primarily to Herbartinian pedagogy and pedagogy focused on philosophical understanding of education. Reformatory pedagogy combines numerous concepts and trends in social and political thought, which was aimed at radical changing the nature of school activities (Dzhurinskiy, 2000).

The ability to analyze and use innovative ideas of the representatives of the latest pedagogical trends in the early 20th century was considered to be an important factor in the development of young teachers' pedagogical mastery. Only a theoretically trained teacher, acquainted with modern scientific terminology, advanced teaching methods and technologies was able to masterfully manage the education process. Graduate teachers acquired the knowledge of individualistic, experimental, social, Herbartinian and monistic (biological) trends in pedagogy.

The representatives of individualistic pedagogy or personality pedagogy (F. Gansberg (1871-1950), H. Gaudig (1860-1923), H. Scharrelmann (1871-1940) et al.) considered the education process to be unlimited creativity of teachers and students, which excluded any suppression of student personality and any regulation of their activities. According to the views of German educators, the system of school education in one way or another harmed the child. Teachers' pedagogical mastery was defined as "advanced pedagogical skills" and consisted in the fact that teachers were guided only by pedagogical tact and rejected all obligatory methods in their activities. Teacher personality and talent were seen as the most important tools of education.

The process of developing child's personality provided for creating favourable conditions for their creative self-development, mainly sustained by aesthetic experience. "The Bremeners take into account neither ideas, nor their change and clarity; they prefer creativity, feelings, which is why they sacrifice them for intellect" (Muzychenko, 1912, p. 7). The organization of students' creative activities was aimed at developing their cognitive activities, namely, writing compositions, solving problem, etc.

The founders of experimental pedagogy ("precision pedagogy", "the new pedagogy") (E. Meumann (1862-1915), W. Lay (1862-1926)) studied general patterns and individual peculiarities of the child's physical and spiritual development by using new research methods. The content of experimental pedagogy accumulated diverse facts of child psychology, physiology and sociology. The main attention was paid to the process of studying the child, rather than the learning process. Such empirical methods as observations, empirical experiments, studying children's works, questionnaires, pedagogical experiments, statistical methods were primarily used during these studies. Schools were to assist children in adapting to school environment, to create a school community that would simulate the natural and social environment. Consequently, teachers were obliged to apply active teaching methods, organize students' practical activities and develop their cognitive skills, etc. 
Social pedagogy (founded by P. Natorp (1854-1924)) emerged due to the fact that the problem of the child in the 20th century was considered to be a social problem. Social pedagogy was to establish the relationship between education and community. The main ideas of P. Natorp's pedagogical system consisted in the following: education should be aimed at developing true citizens of the state of law; the individual can only exist in the human community and due to it; school is the most important center of society and is represented as the union of teachers and students; the content of education is realized through acquisition of scientific, moral, aesthetic and religious beliefs, development of the individual's will, sensitivity and spirituality; will power, clarity of thought and reasoning achieved only due to independent intellectual activities, active reconsideration of study material, rather than mere listening and memorizing should become obligatory elements of children's characters. The criteria for young teachers' erudition were active perception of all human, integrity of thoughts, task performance independence, the unity of reason, will and action (Muzychenko, 1919, p. 70).

The founder of Herbartinian pedagogy is J. Herbart (1776-1841), who viewed pedagogy as science and art. The scholar defined the content of pedagogy as an integral system of knowledge (pedagogy as a science) and associated pedagogy with the skills required to solve a particular pedagogical problem (pedagogy as an art). The school, in his opinion, was supposed to ensure general and comprehensive development of children, to promote their activity and amateur activities, to support their striving self-development.

Solving the children's discipline problem, J. Herbart believed that it was necessary to apply coercive pedagogical influence (threat, supervision, prohibition, children's involvement in various activities, etc.). In addition, the educator noted that the teacher (the artist of education) should mitigate the children's discipline with love ("pedagogical love" as the unity of feelings between teachers and children), whereas the means of pedagogical influence should not cause children's resistance. J. Herbart stated that the teacher being an authoritative educator must take into account individuality of student personality, consider the child to be the highest value and nurture their positive traits. Child management was aimed at involving them into useful activities and interesting lessons.

J. Herbart introduced the concept of "educational teaching" into theory of pedagogy, based on the fact that specific functions of education and teaching are interconnected and complement each other. By presenting the new knowledge, the teacher forms ideological, social and other guidelines, and thus develops the child in general. The scholar considered the development of diverse interests (empirical (motivating towards observation), contemplative (motivating towards reflection), aesthetic (refining the aesthetic taste), sympathetic and social (promoting the feeling of sympathy), religious (spiritual perception of the world)) to be extremely important for the realization of the objectives of educational teaching and the main aim of pedagogical activity (Muzychenko, 1919, p. 25).

Reflecting on the problem of teaching implementation, which was aimed at developing students' diverse interests, J. Herbart introduced the organization of students' educational and cognitive activities, associated with acquisition of the new knowledge as a certain sequence, namely, formal levels of teaching. Herbartinian pedagogy became the most relevant introductory course for young teachers at the beginning of teaching career, since it promoted a complete thought and facilitated the coherent process of mastering knowledge.

J. Herbart outlined clear requirements for professional training, development of pedagogical mastery and individual characteristics of the teacher. The scholar believed that the art of education was acquired only during practical activities and pedagogical tact was 
the "transition" between theory and practice. Moreover, J. Herbart indicated that student freedom is an important condition for achieving the main aim of education.

E. Haeckel (1834-1919) was thought to be an enthusiastic apologist for the monist theory and the founder of the Monist League. His scientific theory was based on continuity of cognition as well as unity, universality, necessity and invariance of world laws, required to develop the true and sustainable worldview (Muzychenko, 1908, p. 13).

E. Haeckel's research interests included the problems of reforming the existing education system in Germany, namely, the theory of school leadership, which studied the influence of church, state, community and family on school, and defining the aim of school education, which would develop the child's independent thinking, clear perception of the acquired knowledge and familiarity with the natural relationships between phenomena; the science of development as a guiding principle in teaching; genetic approach to teaching, aimed at ensuring students' amateur activities; definition of the education content with the prevalence of natural sciences; justification of the teacher's role in the education process organization.

In the context of monistic ideas, the teacher was supposed to prepare the child for life and impart the accumulated experience on them, taking into account individual characteristics. The defining component of teachers' pedagogical mastery was selection of relevant teaching forms.

Based on the analysis of foreign trends in the late 19thh - the early 20th centuries, one can conclude that the world's leading experts in school theory and practice solved identical problems, but diverse approaches led to controversy between them. The concepts of all pedagogical trends were based on the idea that the student was "the object of pedagogical influence", however different trends mainly dealt with development of various characteristics of "self": Herbartinian pedagogy - intellect, individualistic pedagogy feelings, social pedagogy - freedom, experimental pedagogy and monists attempted to equally study and influence different aspects of the child's psyche.

However, it must be noted that one should not formally combine diverse approaches and therefore distinguish the most original ideas of each pedagogical trend. The teacher was supposed "to equally recognize all pedagogical trends" rather than outline the most interesting approaches to teaching (Muzychenko, 1919, p. 90). The principle of labour school became the unifying principle for this matter, since it harmoniously developed student personality, their cognitive activities and worldview. Thus, the mentioned above facilitated the establishment of a unified labour school in Ukraine. In unifiied labour schools, teachers strived to develop their pedagogical mastery, which was understood as the highest level of pedagogical action, expressed through special skills required to professionally apply the principles ensuring development of children's independence and initiative, motivating them toward positive actions and establishing personal responsibility for their behaviour.

The process of developing pedagogical mastery of young teachers was associated with studying the ideas of philosophical and pedagogical trends, the ability to analyze learning objectives, to understand the essence and the peculiarities of the latest educational technologies (developmental and research) and teaching methods (heuristic, task-based, project methods, artistic education methods, trip-based methods, complex learning, etc.) and to operate methodical techniques. This approach was based on good relationships between teachers and students, teachers' care for students and students' respect for teachers. 


\section{CONCLUSIONS}

The analysis of Western European pedagogical trends in the late 19th - the early 20th centuries showed that the process of developing young teachers' pedagogical mastery had been influenced by the ideas of individualistic, experimental, social, Herbartinian and monistic (biological) trends in pedagogy. Thus, the increase in the level of pedagogical mastery was associated with thorough theoretical preparation and acquisition of innovative technologies and teaching methods. Young teachers were supposed to educate active, independent, creative individuals able to change the world around them.

Prospects for further researches involve studying foreign innovative forms, methods and technologies of teaching in the late 19th - the early 20th centuries and relevant trends in their implementation, taking into account national characteristics, application of local history and natural study material.

\section{REFERENCES}

1. Ananiin, S. A. (1924). Trudove vykhovannia, yoho mynule i suchasnist. Kyiv: Knyhospilka.

2. Askerman, M. (1915). Sprava vykhovannia ta osvity v Ukrainskii Sotsialistychnii Respublitsi. Kyiv: I. Kushnarov \& Co.

3. Bunge, M. (1877). Gosudarstvo i narodnoe obrazovanie nachalnoe i professionalnoe, to est uchenoe, realnoe $i$ khudozhestvennoe, v Germanii, Anglii i Frantsii: ocherki issledovaniya Lorentsa Shteina: izvlechennoe iz sochineniya: Das Elementar und Berufsbildungswesen von L. Stein. Kyiv: Universitetskaya tipografiya.

4. Dzhurinskiy, A. N. (2000). Pedagogika: istoriia pedagogicheskikh idei. Moscow: Pedagogicheskoe obshchestvo Rossii.

5. Genkel, G. (1911). Narodnoe obrazovanie na Zapade i u nas. Saint Petersburg: Brokgauz i Efron.

6. Grinko, G. (1923). Nash put na Zapad. Put prosveshcheniia, 7-8, 15-16.

7. Hotalov-Hotlib, A. H. (1929). Formy hrupuvannia uchniv dlia dydaktychnykh tsilei po shkolakh SSHA y Nimechchyny u zviazku z suchasnym pedahohichnym rukhom. Odesa: E. Fesenko's publishing house.

8. Korf, M. (1879). Itogi narodnogo obrazovaniia v evropeiskikh stranakh. Saint Petersburg: Peterburgskii uchebnyi magazin.

9. Levitskiy, A. (1912). Iz teorii i praktiki sovremennoi germanskoi pedagogiki. Kazan: Lito-tip-fiya.

10. Mikhailovskiy, Ya. T. (1881). Ocherk sovremennogo sostoianiia zagranichnoi narodnoi shkoly. Saint Petersburg: Tipografiya Doma prizreniia.

11. Ministerstvo osvity i nauky Ukrainy. (2016). "Nova ukrainska shkola: prostir osvitnikh mozhlyvostei". Proekt dlia obhovorennia. Vziato z https://osvita.ua/doc/ files/news/520/52062/new-school.pdf.

12. Mizhuev, P. (1913). Glavnye momenty v razvitii Zapadno-Evropeiskoi shkoly. Moscow: "Polza" V. Antik i K०.

13. Musin-Pushkin, A. (1912). Sbornik statei po voprosam shkolnogo obrazovaniia na Zapade $i v$ Rossii: po lichnym nabliudeniiam. (T. 1-2). Saint-Peterburg: tipografiya M. Stasiulevicha. 
14. Muzychenko, A. (1912). Konspekt lektsii po pedagogike, prochitannykh na zemskikh letnikh kursakh v Poltave. Narodnaia Entsiklopediia nauchnykh i prikladnykh znani, 9, 134-157.

15. Muzychenko, A. (1908). Monizm i shkola. Russkaya shkola, 4, 3-30.

16. Muzychenko, O. (1919). Suchasni pedahohichni techii v Zakhidnii Yevropi $i$ Amerytsi. Kyiv: Drukarnia Vseukrainskoho kooperatyvnoho soiuzu.

17. Rusova, S. (1910). Narodna pochatkova osvita v Belhii. Svitlo, 1, 29-36.

18. Sukhomlynska, O. V. (1992). Zarubizhnyi pedahohichnyi dosvid v Ukraini v 20-ti roky. Ridna shkola, 2, 3-7.

19. Yanzhul, E. K. (1918). Trudovoe nachalo v shkolakh Evropy. Moscow: Narodnyi uchitel. 